\title{
Hero of Two Ages: Mohd Said Sulaiman as the First Malay Autobiography Editor
}

\author{
Rahimah Hamdan ${ }^{1}$ \& Shaiful Bahri Md. Radzi ${ }^{2}$ \\ ${ }^{1}$ Department of Malay Language, Faculty of Modern Languages and Communication, Universiti Putra Malaysia, \\ Serdang, Malaysia \\ ${ }^{2}$ School of Malay Language, Literature and Culture Studies, Faculty of Social Sciences and Humanities, Bangi, \\ Malaysia \\ Correspondence: Rahimah Hamdan, Department of Malay Language, Faculty of Modern Languages and \\ Communication, Universiti Putra Malaysia, 43400 UPM Serdang, Selangor, Malaysia. Tel: 60-3-8946-8758. \\ E-mail: rahimahhamdan@gmail.com
}

Received: October 16, 2013 Accepted: February 18, 2014 Online Published: March 31, 2014

doi:10.5539/ass.v10n7p191 URL: http://dx.doi.org/10.5539/ass.v10n7p191

\begin{abstract}
This paper discusses the role of an early $20^{\text {th }}$ century Johore intellectual and early Malay autobiography editor named Mohd Said Sulaiman in linking the traditional to the modern era. Mohd Said's prowess as a Johore Malay figure was not only due to the fact that he was an important individual in the government (being the Sultan's private secretary) but that he was also a very prolific scholar in the field of Malay literature. He produced several Malay literary works, either in prose or poetry, culminating in the completion of the major task of introducing these works to Sultan Ibrahim of Johore, who finally decreed that Ibrahim Munsyi's autobiography be printed and edited in a scholarly manner without altering its contents. Thus began Mohd Said Sulaiman's journey as the link between the traditional era (the era of the manuscript) and the modern era (the printing press) until this work could continue in the form of the text as it is today. As a result, Kisah Pelayaran Muhammad Ibrahim Munsyi was successfully published for the first time in 1919. The Japanese Occupation of Malaya until 1945 resulted in the disappearance of the original manuscript on Ibrahim Munsyi. The only evidence of the existence of the early autobiography for the Malay community was Mohd Said Sulaiman's publication in 1919. It is apparent that the contribution of the late Mohd Said also paved the way and provided useful input to the history of Johore and the West Coast of Peninsular Malaysia, which all along had only relied on the reports of British officials, which were slanted more towards 'white supremacy'. Indirectly, the complete works edited by him can promote the study of various disciplines such as social studies. Research has shown that Mohd Said Sulaiman is one of the greatest literary figures of Johore because of his far-sighted vision, which gained prominence for the Johore Government on the world stage.
\end{abstract}

Keywords: era, traditional, modern, Malay, Ibrahim Munsyi

\section{Introduction}

Literary circles in this country, or even in Indonesia and Brunei, are more familiar with Munsyi Abdullah than with his son, Ibrahim Munsyi. The title 'Father of Modern Literature' or 'Father of Malay Printing' is very much synonymous with Munsyi Abdullah, even though his works in the mid-19 ${ }^{\text {th }}$ century shocked the traditional Malay society. Several local scholars, such as Khalid Hussain (1964); Hassan Ahmad (1976); Kassim Ahmad (1981); Siti Hawa Salleh (2009), and Western scholars such as Hill (1970); Roff (1972); Skinner (1978); Sweeney (1980); Milner (1980); and Bastin (1983) just to name a few, have given various justifications for Abdullah's works because of the changes that he brought to conventional Malay literature. It is said that while the works of Munsyi Abdullah attempted to challenge the conventions supported by the Malay community at that time, the works of his son, Ibrahim Munsyi, on the other hand was accepted and in fact became the pride of HRH Sultan Ibrahim, the ruling monarch at that time, who ordered the printing of Kisah Pelayaran Ibrahim Munsyi because of its great importance to Johore's treasury of knowledge (Sweeney \& Phillips, 1975; Sweeney, 1980; Othman, 1980).

It is very impressive that among the many intellectuals and scholars in Johore at that time (the end of the 19th century), Mohd Said Sulaiman was chosen by Sultan Ibrahim of Johore to complete the assignment. The 
significance of Mohd Said Sulaiman's services is also undeniable because without the initiative from him to introduce this work to Sultan Ibrahim of Johore, this manuscript would definitely not have been printed, what more to be academically edited without altering its contents. Thus, it is here that Mohd Said Sulaiman played a role as the link between two eras in Malay literature, i.e. the traditional era (the era of the manuscript) and the modern era (the era of the printing press) until this work can be enjoyed in the form of a text as it is today. Accordingly, this study will identify how Mohd Said Sulaiman, as an editor, united two eras through Kisah Pelayaran Ibrahim Munsyi. What was the effect of this editing on local and international research? Indirectly, through this study as well, the name of Ibrahim Munsyi can be promoted as an individual who has contributed significantly to the corpus of Malay literature because it is obvious that his autobiography, unlike the writings of his father, Munsyi Abdullah, was intended for the advancement and interests of the Malay community as his target audience and not the British.

\section{Traditional and Modern Conventions}

The undertaking of compositions in the traditional Malay literature corpus must take into consideration certain conventions in order to be accepted by the public as well as the king as the patron of such literary activities (Sweeney, 1987: Siti Hawa Salleh, 1997 and 2009; Koster, 1997; Braginsky, 2004). Accordingly, authors of traditional Malay literature are bound by these conventions that restrict their freedom to write, even though to them that is the 'reasonableness' that is expected of Malay writers. Furthermore, the close connection between oral and written literature is among the many factors that lead to additions, reductions and modifications to the contents that are copied by writers (Sweeney, 1987: 1).

Traditional Malay literature is the 'product of the court' (Sweeney 1980: viii). Works that are composed and heard begin in the palace as the main centre for the development of knowledge. Every literary work must satisfy the king as the patron of the arts and the works must be functional for the audience (Sweeney and Phillips, 1975: xxii):

'In this society, where individualism was not encouraged, originality of composition was not a criterion of good literature, although it cannot be denied that there was some scope for creativity within the bounds of convention. Every copyist of secular literature was a potential re-writer. Writers concerned themselves with kings, princes and the palace life, ignoring entirely the common man. Moreover, the writer as an individual remained well in the background. The reading public, in this age of manuscript literature and widespread illiteracy, was obviously limited, but works were sometimes read aloud to audiences or adapted for performance in dramatic genres such as the shadow-play, so that the society was often well-acquainted with the content of such works'.

Court authors who write for the Malay historiography genre such as Sulalatus Salatin (Sejarah Melayu), Tuhfat al-Nafis and several others love to include elements of myths and legends in their writings. This is consistent with the thinking and world view of the Malay community, which considers such elements as an undeniable 'truth'. Although these elements have been severely criticized by Western scholars, who are very objective when it comes to the writing of history, for the Malays this is a convention that must be acknowledged in order to endorse the monarchy as well as the hereditary rule. These elements of myths and legends are capable of lifting the honour of the king above that of the kings of other Malay kingdoms until these are considered as important 'combat de prestige' elements of the Malay historiographical (Sweeney \& Phillips, 1975: xxii):

'[...] Malay society made no distinction between writing as an art and a craft, so that, on the one hand, official correspondence or such an unlikely subject as a code of laws could become work of art in skilled hands, and on the other a 'writer' would not merely expect to perform the duties of a clerk but also to produce literacy works for entertainment and edification'.

British colonialism in the 18th and 19th centuries was a major blow to the Malay world, bringing with it various social, political and economic transformations in the society (Johns, 1979; Gullick, 1987; Ungku Maimunah 1987; Hooker, 2000; Milner, 2002). Malay literature was also influenced to the extent that the writing conventions inherited over the years were subverted. The emergence of new personalities such as Ahmad Rijaluddin and Munsyi Abdullah, who were said to have written Malay literature for the European courts, introduced a new convention in the field of Malay literature by demolishing the royal institution as the centre for literary works, bestowing on writers the freedom to write according to their creativity and based on the reality (realism) (Skinner, 1978, 1983; Sweeney, 1980). Skinner (1978) introduced the term 'transitional literature' to categorise the changes where Abdullah was said to have still employed traditional elements such as style and language nuances, although his writings were purely critical and individualistic. Abdullah is hailed as the "Father 
of Modern Literature' for his courage, passion and vision in changing the writing conventions of the Malay community, such as the adoption of individualistic elements, which differed from those of previous writers. These elements were termed as 'modernisations' in Malay literature before several local scholars, such as Al Attas (1969), Hassan Ahmad (1976) and Hadijah Rahmat (2001), just to name a few, were of the opinion that Abdullah did not reflect true Malay values in his writings.

The Malay community also experienced changes in moving from the traditional era to the modern era because of the introduction of the printing system by the colonialists, which transformed the concept of Malay literature (Hussein, 1974: 1). Gallop (1990: 182) called Munsyi Abdullah the 'Father of Malay Printing' because it was through him that lithography technology was introduced to the Malay community. Van der Putten (1997: 718) quoted Peter in his opinion that it was obvious that the first Quran was printed in Palembang in 1848 but Munsyi Abdullah's name is written in the colophon section of the Quran as the teacher of the individuals who printed the Quran. He also added the lithography printing technique was introduced in the Archipelago region by British missionaries (Medhurst) (van der Putten, 1997: 717). They began lithography printing in Batavia in 1828. Then, when the American and British missionaries moved to China (1840), printing activities in Singapore became the responsibility of Reverend Keasberry. Keasberry in turn had a good relationship with Munsyi Abdullah who had also learned this printing technique from the missionary, Medhurst. The introduction of printing marked the beginning of the era of 'modernisation' in Malay literature and made room for the development and wider dissemination of knowledge as a consequence of the reforms brought about by that 'modernisation' (Rahmat, 2001). According to Proudfoot (1992: 52) the introduction of printing technology gave birth to a form of cultural commodity in a new world of literature. This technology not only transformed the old text to a new one, but also the new text to other copies. Proudfoot (1997: 52) also stated that the new literature gave rise to 'modern' conventions that got rid of several problems that were encountered in traditional manuscripts as below:

'The reluctant of some many script owners to lend stems from the same conflict of values. [...] they feared that their valuable property would be damaged or simply not returned. Only if the manuscript was lost, could they legitimately claim monetary compensation. The deeper intrusion of the commercial values of the urban market-place into manuscript transactions is evident in the commercial manuscript lending libraries of the early nineteenth century, with set fees calculated by the night. Printing ultimately undid these social bonds. It undermined the professional reciter's livelihood, the ruling house's monopoly and began to release the private owner of a text from entanglement in fraught social relations.'

Malay literature was introduced in autobiographical writings pioneered by Ahmad Rijaluddin and Munsyi Abdullah. The difference between the two of them was that Abdullah was a highly outspoken critic of his own people, and the Malay community considered this as 'awkward' and 'embarrassing'. His writings were seen as being ego-centric even though Munsyi Abdullah gave a new discourse to Malay literature. In comparison, his son, Ibrahim Munsyi, was the sultan's favourite until he became known as the 'Maharaja's man' (Sweeney \& Phillips, 1975: xxvii). He served as a language teacher (munsyi) to the Europeans, and was later selected as the 'palace writer' by Sultan Abu Bakar of Johore, who sent him to accompany the fourth state voyage in the West Coast of Peninsula Malaysia from 1871 to 1872, which resulted in the writing of Kisah Pelayaran Ibrahim Munsyi (1872). This earned him the title of Dato' Bentara Dalam in 1886. With the death of Ibrahim Munsyi in 1904, the manuscript, Kisah Pelayaran Ibrahim Munsyi, could not be printed. Thus, it was here that the name Mohd Said Sulaiman appeared as the person who introduced this manuscript to Sultan Ibrahim of Johore in 1917. Consequently, 41 years after the death of the author of this manuscript, Mohd Said Sulaiman was entrusted with the responsibility of printing this manuscript on the orders of Sultan Ibrahim, as mentioned in the introduction to Kisah Pelayaran Ibrahim Munsyi dated 30 May 1917 as below:

'Datuk Muhammad has been determined to be Haji Muhammad Said, who together supervised the stamping of this book, corrected each word and spelling, and checked that none of the details had been changed; on the expense of the government because this book is useful to Johore'.

\section{Hero of Two Ages: Kisah Pelayaran Muhammad Ibrahim Munsyi and Mohd Said Sulaiman}

Mohd Said Sulaiman was among the prolific Malay writers in the early 20th century (Maier, 2006: 28) until he was appointed a member of the Malayan Branch of the Royal Asiatic Society (MBRAS) in 1922. He started working as a clerk with the British and Foreign Bible Society in Singapore, and it was there that a new chapter was opened in his life when he began to immerse himself in the world of writing and honed his talent to become a writer (Noor, 2011: 55). His introduction to Sultan Ibrahim in 1898 led him to contribute his services to the Johore government as a teller and this directly gave him the opportunity to mingle with the Johore royalty and 
literary figures such as Muhammad Ibrahim Munsyi as well as Abdullah bin Abdul Rahman. Mohd Said Sulaiman gained the trust of Sultan Ibrahim and was appointed the Sultan's Private Secretary after serving as the Postmaster General from 1989 to 1902 . As an employee of the Johore state government it was compulsory for him to be involved in the Johore Military Forces (JMF) (Noor, 2011: 55). His love for Malay literature caused him to take the initiative to introduce Ibrahim Munsyi's autobiography (Kisah Pelayaran Ibrahim Munsyi) to the Sultan of Johore. Therefore, when Mohd Said Sulaiman became a Captain in 1917, the sultan entrusted him with the task of completing the printing of the manuscript. He needed to print a manuscript that was almost half a century old (47 years) and that had probably long been exposed to the passage of time and the effects of the weather that could have altered its quality. Nevertheless, for Mohd Said Sulaiman, nothing could stop him from completing the task, not to mention that before the work could be printed it had to undergo various editing processes without any changes to its contents so that it could more easily be read by the public and future generations. Here, Mohd Said Sulaiman used his experience and expertise in the field of Malay and English writing to complete the task of editing and systematically organizing the printing of the work to facilitate its reading by members of the public, especially the future generation. Indirectly, Mohd Said Sulaiman tried to integrate two eras, that is, the traditional (manuscript) and the modern (lithograph). Compared to the other Johore Court officials, Mohd Said Sulaiman was chosen to print a piece of work that was very valuable to the government. However, nothing was impossible for Mohd Said Sulaiman (Za'ba, 1941:17):

'Never be afraid that your writing is too poor or your fact is fault. Abler people will correct you and improve on what you have begun by producing better works. If every writer were afraid to write because people may laugh at his shallowness, there would have been no books in the world.'

One thing that was interesting about the autobiography, Kisah Pelayaran Ibrahim Munsyi, was that its second printing (1956) was based on the first edition that was printed in 1919 because the original manuscript was lost during the Japanese Occupation (Sweeney \& Phillips 1975: xxxiii). Thus, it can be said that without Mohd Said Sulaiman's efforts to introduce and print the works of Ibrahim Munsyi, it would be impossible for the present generation to know about the existence of a Malay autobiographical work other than the writings of Ahmad Rijalludin and Abdullah Munsyi. One hypothesis could be that possibly the original manuscript written by Ibrahim Munsyi was still in its raw form and required systematic and structured reading markers that could only be done by individual experts in the field of Malay linguistics and literature. Mohd Said Sulaiman was a qualified individual as it was he who facilitated the reading and comprehension of this work (1919) and not Ibrahim Munsyi, as the main author of the manuscript.

The following are evidences of the editing that was done by Mohd. Said Sulaiman on the Kisah Pelayaran Ibrahim Munsyi manuscript:

\subsection{Notice on Title Page}

Mohd Said Sulaiman stated, "Composed by him before he was bestowed the title Datuk Bentara Dalam in Johore for his voyages." The pronouns in the third person show that some other individual is being referred to. Thus, it can be said that this title page was written by Mohd Said Sulaiman and not by the original author and was meant to introduce the real author to the audience before they reviewed his work.

\subsection{Foreword}

It was Mohd Said Sulaiman who wrote and inserted it into the manuscript before it was printed so as to inform people as to the background and history that led to this printing as follows: 'Now this tale, written by its author, Ibrahim bin Haji Abdullah Munsyi, is accompanied by the declaration that the editing tasks were carried out by the person mentioned at the end of the page, that is:

'May Allah Subhanahu wa ta'ala bestow long life to His Majesty and preserve the government of

Johore for his descendants, granting them safety and peace forever.

Haji Muhammad Said,

Captain, Johore Military Forces'.

\subsection{A Detailed and Structured List of Contents}

Mohd Said Sulaiman prepared a list of contents based on the original manuscript as given below:
First voyage
$=16$ sub-topics (including the first and last page)
Second voyage
$=1$ sub-topic (including the first and last page)
Third voyage
$=2$ sub-topics (including the first and last page) 
Fourth voyage $\quad=9$ sub-topics (including the first and last page)

Fifth voyage $\quad=38$ sub-topics (including the first and last page)

3.4 Pages with Written Page Numbers

Kisah Pelayaran Ibrahim Munsyi was compiled by Mohd Said Sulaiman to include the page number on every page for easy reference. According to Mohd Said Sulaiman, this work has 80 printed pages altogether.

\subsection{Division of Chapters and Systematic Format}

Mohd Said Sulaiman arranged the chapters according to the chronology of the stories, although the page numbers began with the largest number to the smallest (for example, page 4-1,5-4) and the use of the hyphen (-) meant 'until' as given below:

Index

\section{First Voyage}

The Tale of My Departure to Padang and then Melaka

About the Country and its people (Parit Jawa)

Tin Works

Idioms

$[\ldots]$

Connection Upstream

[...]

\section{Fifth Voyage}

[...]

Perak Treaty

$80-77$

\subsection{Use of Punctuation Marks}

Punctuation marks are symbols that have no connection with the phenomena or phrases in a sentence but play a role in indicating the structure and organisation of a writing and the intonation to be observed when reading. In Kisah Pelayaran Ibrahim Munsyi, Mohd.Said Sulaiman used several punctuation marks (“...”) and placed them exactly and appropriately in sentences to indicate that a conversation was taking place between two individuals as in the extract below:

'Soal Tuan Irving --- “Apa khabar Tengku di manakah ada seorang Syed Mashor dan Raja Kahar dan Raja Mahmud itu dan di mana Raja Mahadi dan Raja Hitam.'

'[Ask Mr. Irving --- "How're you Tengku and where is Syed Mashor, Raja Kahar and Raja Mahmud, also Raja Mahdi and Raja Hitam] (Muhammad Ibrahim Munsyi, 1956: 39)'.

The dash (---.) emphasizes that there is another position or explanation to assert the sentence in linking two words, that is:

'Fasal yang pertama --- Maka Raja Muda Abdullah itulah disebut menjadi Sultan Perak.

[The first section --- Then Raja Muda Abdullah is called the Sultan of Perak]' (Muhammad Ibrahim Munsyi, 1956:78).

'Fasal yang kedua --- Maka Raja Bendahara Ismail yang ada jadi pemangku Sultan itu, ditanggungkan kepadanya gelaran Sultan Muda serta mendapat pencen dan satu jajahan kecil terserah menjadi punya kepadanya'.

'[The second section --- Then Raja Bendahara Ismail who acting as the king, currently called as Sultan Muda, he get a pension and a small colony] (Muhammad Ibrahim Munsyi, 1956: 78)'.

Consequently, it is apparent that Mohd Said Sulaiman did a great thing indeed in editing the work of Ibrahim Munsyi because without his efforts this early Malay autobiography would remain unknown and would be swallowed up in time. Based on the second printing of Kisah Pelayaran Ibrahim Munsyi in 1956, this text was published by Markum bin Haji Mohamed Said at the Johore State Printing Office in 1919, while Proudfoot (1993:633) was of the opinion that this text was published at the Methodist Publishing House in Singapore in 1919 as recorded in the Government Gazette. Regardless of where this work was printed, it is a valuable Malay 
treasure especially in explaining the reality of what took place concerning the king and the community in the west coast area (specifically the Malays) during the British colonial period. Without the services of Mohd Said Sulaiman, it is highly possible that the community would not have known Ibrahim Munsyi as the earliest Malay literary figure other than his father, Munsyi Abdullah, and Ahmad Rijalludin, until he succeeded in introducing a new discourse (autobiography) into the world of Malay writing, particularly in modern Malay literature. Thus, it can be said that Mohd Said Sulaiman was a personality who succeeded in bridging two eras, the traditional and the modern, by extending the life of a manuscript into a printed material (lithograph) and giving a new face to an old manuscript through systematic editing so that Kisah Pelayaran Ibrahim Munsyi could continue to contribute to the development of knowledge in the country.

\section{Kisah Pelayaran Muhammad Ibrahim Munsyi and the Research Disciplines}

The second edition of Kisah Pelayaran Ibrahim Munsyi in 1956 succeeded in opening the way to a variety of scientific studies in various disciplines, particularly the study of Social Science and Humanities.

\subsection{History Discipline}

Through his writings, Ibrahim Munsyi described the life of a Malay warrior at the end of the $19^{\text {th }}$ century who deeply loved his religion and his language. His strong spirit of struggle in upholding his race, as outlined in his writing, made even the British highly respectful of his stance. The wisdom of Ibrahim Munsyi in keeping a balance between his job as a translator for the British and the Malay rulers made him well-liked by both parties. Most of the historical resources of Malaysia are based on the entries and reports of the English officers, which were bent more towards the perspective of white supremacy. Ibrahim Munsyi's entries were more open and wise, coming from a Malay-Muslim working for the English officers (local views). Kisah Pelayaran Ibrahim Munsyi was found to have been written more in a historical sense because Ibrahim wrote "not once have I added to or diminished what I heard'. Furthermore, Ibrahim was greatly influenced by the writing of John Cameron in 1865 titled Our Tropical Possessions in Malayan India (Sweeney \& Phillips 1975: xxx), who also mentioned interesting places in Penang in his entries. He also included several attachments, which no Malay auto biographer had done before, and stated that it was "for this age and for the knowledge of those who come in the later ages" (Muhammad Ibrahim Munsyi, 1956:79).

\subsection{Literary and Linguistic Disciplines}

Studies can be carried out regarding the change from the traditional to the modern convention that was brought about by Ibrahim Munsyi, who was more honest than his father, Abdullah, and Ahmad Rijalludin, in his comments about the Malays. In addition, Ibrahim built a new discourse (autobiography), which had all along been viewed as something that was foreign to Malay. literature Although his language nuances and writing style were still traditional in nature, the narrative content was no longer centred on the world of myth and fantasy to fulfil certain functions and goals. The values and thinking of Ibrahim Munsyi as the author of Malay literature at the 'threshold' of the modern era can be explored, especially his concern for the plight and problems plaguing the Malay community at that time, namely:

1) Grief over the laziness that had been haunting the Malays since time immemorial, as expressed in Sweeney (1980:18):

'Unlike his father, Ibrahim clearly took pride in being a Malay, and his undivided loyalties were with his Malay raja. This is reflecting in his writing. Although he used The Kisah Pelayaran Abdullah as a model for his Kesah Pelayaran Ibrahim Munsyi, his postulated audience was Malay and this explains why Malays are better able to appreciate his writings than those his father'.

2) Great concern over the proper use of the Malay language, especially in speech (formal) and writing.

3) Disappointment over the Anglophile attitude of the Malay rulers and their descendants, that is:

'On hearing that Kudin and Syed Zain have given English names to all the streets in Klang, he expressed his dismay that Malay names have not been used and remarks that some modification is necessary when English usage are adopted by a Malay state' (Sweeney dan Phillips 1975: xxix)

4) His entries were based on research and were not merely blind criticisms to curry favour with the English dignitaries (Sweeney and Phillips, 1975:xxx):

'His voyages do not merely consist of a bare narratives of events but include the results of his often quite extensive research into a variety of topics such as the origin of a keramat in Penang, the background of Ngah Ibrahim and his father Long Ja'afar and the working of the Perak Constitution. He does not confine himself to description but also attempts some analysis of the various problem 
he encounters, for example of the political situations in Klang, Larut dan Perak. [..] Also contain detailed accounts of confidential interviews between Irving the Auditor-General [...]'.

5) He was an intellectual who managed to balance two different cultures (Malay and English).

\section{Conclusion}

Kisah Pelayaran Ibrahim Munsyi, an essay by Ibrahim Munsyi and edited by Mohd Said Sulaiman, had a great impact on the world of Malay literature. It began a discourse based on the elements of reality, instead of myths and legends, to fulfil certain functions and goals, thus implying the emergence of a new perspective in the literary scene, which directly signalled a change from the traditional to the modern age. Mohd Said's work in 'reviving' Ibrahim Munsyi's writing encouraged the publication of several autobiographies and biographies by other Johore writers, such as the writing of Dato' Mohamed Salleh Perang's Tarikh Datuk Bentara Luar Johor. Indirectly, this complete work that was edited by Mohd Said Sulaiman intensified studies into various disciplines in the fields of Social Science and Humanities, such as History, literature, Linguistics and several others (Political Science, Geography, Sociology and so on). Thus, it comes as no surprise that Kisah Pelayaran Ibrahim Munsyi prompted two international literary scholars, Amin Sweeney and Nigel Phillips, to do a transliteration (from Jawi to roman script) and to translate it to English. The work was then published by Oxford University Press in 1975 so that it could be more widely introduced to the international community interested in Southeast Asian studies. This was due to Mohd Said Sulaiman's passion as a literary figure from Johore whose far-sighted vision turned the spotlight on the Johore Government on the world's stage.

\section{References}

Ahmad, H. (1976). Sastra Melayu Moden Semenjak Munsyi Abdullah. In A. Ridhuan (Ed.), Di Sekitar Pemikiran Kesusasteraan Malaysia 1957-1952. Kuala Lumpur: Dewan Bahasa dan Pustaka.

Ahmad, K. (Ed.). (1981). Kisah Pelayaran Abdullah. Kuala Lumpur: Penerbit Fajar Bakti Sdn.Bhd.

Ahmad, Z. A. (1941, February). Recent Malay Literature. Journal of the Malayan Branch of the Royal Asiatic Society, (19), 1-20.

Al-Attas, S. M. N. (1969). Preliminary Statement on a General Theory of the Islamization of the Malay-Indonesian Archipelago. Kuala Lumpur: Dewan Bahasa dan Pustaka.

Bastin, J. (1983). The Missing Second Edition of C.E. Thomsen and Abdullah bin Abdul Kadir's English and Malay Vocabulary. Journal of the Malaysian Branch of the Royal Asiatic Society, 56(1), 10-11.

Booth, W. C. (1961). The Rhetoric of Fiction. Chicago: The University of Chicago Press.

Braginsky, V. L. (2004). The Heritage of Traditional Malay Literature: A Historical Survey of Genres, Writings and Literary Views. Singapore: Institute of Southeast Asian Studies.

Gallop, A. T. (1990). Early Malay Printing: An Introduction to the British Library Collection. Journal of the Malaysian Branch of the Royal Asiatic Society, 63(1), 85-124.

Gullick, J. M. (1987). Malay Society in the Late Nineteenth Century. Singapore: Oxford University Press.

Hill, A. H. (1970). The Hikayat Abdullah. Kuala Lumpur: Oxford University Press.

Hooker, V. W. (2000). Writing a New Society: Social Change through the Novel in Malay. New South Wales: Allen and Unwin.

Hussain, K. (1964). Menempatkan Sejarah Melayu Dalam Kesusasteraan Melayu Klasik Dan Sejarah. Dewan Bahasa, 8(6), 266-272.

Hussein, I. (1974). Sastera dan Masyarakat. Kuala Lumpur: Penerbit Pustaka Zakry Abadi.

Jan van der Putten. (1997). Printing in Riau: Two Steps towards Modernity. Bidragen tot de Taal-, Land- en Volkenkunde, 153(4), 717-736.

Jan van der Putten. (2008). Abdullah Munshi and the Missionaries. Bijdragen tot de Taal-, Land- en Volkenkunde, 162(4), 408-440. http://dx.doi.org/10.1163/22134379-90003661

Johns. A. H. (1979). Cultural Options and the Role of Tradition. A Collection of Essays on Modern Indonesian and Malaysian Literature. Canberra: Faculty of Asian Studies in Association with the Australian National University Press.

Kaptein, N. (1993). An Arab Printer in Surabaya in 1853. Bidragen tot de Taal-, Land-en Volkenkunde, 149(2), 356-362. http://dx.doi.org/10.1163/22134379-90003131 
Koster, G. L. (1997). Roaming Through Seductive Gardens. Leiden: KITLV Press.

Maier, H. (2004).We Are Playing Relatives: A Survey of Malay Writing. Singapura: Institute of Southeast Asian Studies.

Maier, H. (2006). Explosions in Semarang: Reading Malay Tales in 1895. Bidragen tot de Taal-, Land-en Volkenkunde, 162(1), 1-34. http://dx.doi.org/10.1163/22134379-90003672

McGann, J. (1991). The Textual Condition. Princeton: Princeton University Press.

Milner, A. (2002). The Invention of Politics in Colonial Malaya. Cambridge University Press: Cambridge.

Milner, A. C. (1980). A Misionary Source for a Biography of Munshi Abdullah. Journal of the Malaysian Branch of the Royal Asiatic Society, 53(1), 111-119.

Munsyi, M. I. (1956). Kisah Pelayaran Muhammad Ibrahim Munsyi. Johor Bahru; Johore State Printing Office.

Murad, S. A. (1986). Abdullah Munsyi dan Masyarakat Melayu. Kuala Lumpur: Dewan Bahasa dan Pustaka.

Noor, A. M. (2011). Mohd. Said Sulaiman: Cendekiawan Terbilang Johor. Johor: Yayasan Warisan Johor.

Othman, M. F. (1980). Kisah Pelayaran Ibrahim Munsyi (Dengan Pengenalan dan Anotasi). Kuala Lumpur: Dewan Bahasa dan Pustaka dan Kementerian Pelajaran Malaysia.

Proudfoot, I. (1986). A Formative Period in Malay Book Publishing. Journal of the Malaysian Branch of the Royal Asiatic Society, 59, 101-132.

Proudfoot, I. (1993). Early Malay Printed Books. Kuala Lumpur: Akademi Pengajian Melayu dan Perpustakaan Universiti Malaya.

Proudfoot, I. (1995). Early Muslim Printing in Southeast Asia. Libri (Copenhagen), 45, 216-223.

Proudfoot, I. (1997). Mass Producing Houri's Moles or Aesthetic and Choice of Technology in Early Muslim Book Printing. In P. G. Riddell, \& A. H. Johns (Eds.), Islam: Essays on Scripture, Thought and Society (pp. 161-184). Leiden: Brill.

Rahmat, H. (2001). In Search of Modernity: A Study of the Concepts of Literature, Authorship and Notions of Self in 'Traditional' Malay Literature. Kuala Lumpur: Akademi Pengajian Melayu, Universiti Malaya.

Roff, W. R. (1972). Autobiography and Biography in Malay Historical Studies. Singapore: Institute of Southeast Asian Studies.

Salleh, S. H. (1997). Kesusasteraan Melayu Abad Kesembilan Belas. Kuala Lumpur: Dewan Bahasa dan Pustaka.

Salleh, S. H. (2009). Kesusasteraan Hikayat Melayu dan Karya Munshi Abdullah. In Kelopak Pemikiran Sastera Melayu (pp.70-79). Bangi: Universiti Kebngsaan Malaysia.

Sharpe. L. T. (1994). Editing, Fact and Fiction: A Concise Guide to Book Editing. Cambridge: Cambridge University Press. http://dx.doi.org/10.1017/CBO9780511527111

Skinner, C. (1976). The Author of the "Hikayat Perintah Negeri Benggal. Bijdragen tot de Taal-, Land-en Volkenkunde, 132(2), 195-206. http://dx.doi.org/10.1163/22134379-90002639

Skinner, C. (1978). Transitional Malay Literature: Part 1 Ahmad Rijaluddin and Munshi Abdullah. Bijdragen tot de Taal-, Land- en Volkenkunde, 134(4), 466-487. http://dx.doi.org/10.1163/22134379-90002582

Skinner, C. (1983). Munshi Abdullah's "Horrible Murder"- the Ceretera Darihal Haji Sabar Ali. Bijdragen tot de Taal-, land- en Volkenkunde, 139(2), 320-347. http://dx.doi.org/10.1163/22134379-90003447

Sweeney, A. (1980). Reputations Live on: An Early Malay Autobiography. Berkeley: University of California Press.

Sweeney, A. (1987). A Full Hearing. Orality and Literacy in the Malay World. Berkeley: University of California Press.

Sweeney, A., \& Pillips, N. (1975). The Voyages of Mohamed Ibrahim Munshi (Translated with an Introduction and Notes). Kuala Lumpur: Oxford University Press.

Tahir, U. M. M. (1987). Modern Malay Literary Culture: A Historical Perspective. Singapore: Institute of Southeast Asian Studies. 


\section{Copyrights}

Copyright for this article is retained by the author(s), with first publication rights granted to the journal.

This is an open-access article distributed under the terms and conditions of the Creative Commons Attribution license (http://creativecommons.org/licenses/by/3.0/). 